\title{
Vanadate increases cell surface insulin binding and improves insulin sensitivity in both normal and insulin-resistant rat adipocytes
}

\author{
J. W. Eriksson, P. Lönnroth and U.Smith \\ Department of Medicine II, University of Gothenburg, Sahlgren's Hospital, Gothenburg, Sweden
}

\begin{abstract}
Summary. The aim of this study was to elucidate the acute effects of vanadate on cell surface insulin binding and insulin sensitivity in rat adipocytes. The cells were preincubated at $37^{\circ}$ for $20 \mathrm{~min}$ followed by energy depletion with potassium cyanide, extensive washing and ${ }^{125} \mathrm{I}$-insulin binding. The presence of vanadate or insulin during the preincubation period dose-dependently enhanced ${ }^{125}$ I-insulin binding to normal adipocytes (maximally 4-5-fold) through an increased number of binding sites without any change in receptor affinity. Submaximal concentrations of vanadate added together with insulin enhanced the cellular sensitivity to the effect of insulin to stimulate 3-O-methylglucose transport.
\end{abstract}

Vanadate, but not insulin, was also capable of increasing insulin binding as well as insulin sensitivity in insulin-resistant cells (treatment with $\mathrm{N}^{6}$-monobutyryl cAMP or amiloride and adipocytes from obese, aging rats). There was a correlation between the effect of vanadate to augment insulin binding and its ability to enhance cellular insulin sensitivity. Thus, the data suggest that short-term vanadate treatment improves insulin sensitivity through enhanced receptor binding and that this occurs in both normal and insulin-resistant cells.

Key words: Vanadate, insulin receptor, insulin binding, glucose transport, insulin sensitivity, tyrosine kinase activity.
Vanadate is known to mimic several effects of insulin including the stimulation of glucose uptake and oxidation, glycogen synthesis as well as the anti-lipolytic effect [1-6]. The mechanisms for these effects of vanadate are still not completely understood. Vanadate inhibits the $\mathrm{Na}^{+}-\mathrm{K}^{+}-$ ATPase but this effect has proven irrelevant for its insulinlike action [3]. In recent years much interest has been focused on the insulin receptor tyrosine kinase, which is activated by insulin and vanadate $[4,7,8]$ and may be involved in signal transmission including that for the glucose transport system $[9,10]$. However, there is also evidence that the insulin-like effects of vanadate can occur independently of tyrosine kinase activation $[11,12]$. Thus, the role of this enzyme for vanadate action is still not clear. Green [13] suggested that vanadate entirely acts at a postreceptor level, since its effects were demonstrable in cells where the insulin receptors had been down-regulated or digested by trypsin.

The interaction between vanadate and the binding capacity of the insulin receptor at the cell surface has not been thoroughly investigated previously. Earlier studies have indicated that vanadate can decrease insulin binding in human monocytes and lymphocytes [14] and also in rat adipocytes following prolonged exposure [15]. However, the opposite has also been found [8] and a recent study re- ported increased receptor affinity following vanadate treatment of rat adipocytes [16]. We have recently found that insulin itself as well as vanadate is able to rapidly enhance the number of cell surface insulin binding sites [17].

The aim of the present study was to further elucidate the interaction between vanadate and the binding of insulin to its receptor in both normal and insulin-resistant rat adipocytes. Following vanadate treatment, the cells were energy depleted to stop receptor cycling, thus allowing assessment of cell surface insulin binding [16-22]. In order to examine the effect of an altered binding on cellular insulin sensitivity, the dose-response relationship for the effect of insulin on glucose transport was also studied.

\section{Materials and methods}

\section{Materials}

Porcine monocomponent insulin and ${ }^{125} \mathrm{I}$-insulin (sp.act. 200$300 \mu \mathrm{Ci} / \mu \mathrm{g}$ ) were purchased from Novo (Copenhagen, Denmark). ${ }^{14} \mathrm{C}-3-\mathrm{O}$-methylglucose (sp. act. $59 \mu \mathrm{Ci} / \mu \mathrm{mol}$ ) was from Amersham (Amersham, Buckinghamshire, UK) and ${ }^{32}$ P-ATP (sp.act. $3 \mathrm{Ci} / \mu \mathrm{mol})$ ) from DuPont (Geneva, Switzerland). Collagenase, bovine serum albumin (fraction V, BSA), wheat germ agglutinin (WGA), Glu ${ }^{80} \mathrm{Tyr}^{20}, \mathrm{~N}^{6}$-monobutyryl cyclic AMP ( $\mathrm{N}^{6}$-mbcAMP), 


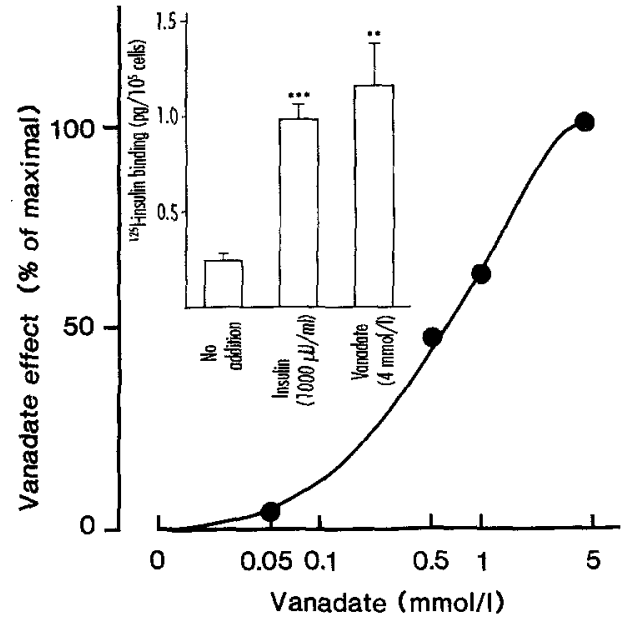

Fig. 1. Effect of vanadate (or insulin) on ${ }^{125}$ I-insulin binding in normal rat adipocytes. Adipocytes were preincubated at $37^{\circ} \mathrm{C}$ for $20 \mathrm{~min}$ with or without insulin and vanadate at the indicated concentrations. Following the addition of $\mathrm{KCN}$ and extensive washing, ${ }^{125} \mathrm{I}-$ insulin binding was performed at $16^{\circ} \mathrm{C}$ as described in "Materials and methods". Data are means \pm SEM from eight separate experiments (insert) or from one representative experiment repeated four times. ** $p<0.01$, **** $p<0.001$ compared to no addition

amiloride and protease inhibitors were from Sigma Chemical Co (St. Louis, Mo., USA). Adenosine deaminase (ADA) was obtained from Bochringer Mannheim (Mannheim, FRG), and sodiumorthovanadate $\left(\mathrm{Na}_{3} \mathrm{VO}_{4}\right)$ from $\mathrm{BDH}$ Chemicals Ltd (Poole, Dorset, UK). Medium 199 was obtained from Statens Bakteriologiska Laboratorium (Stockholm, Sweden).

\section{Cell preparation and incubation conditions}

Male Sprague-Dawley rats, fed ad libitum, were stunned and decapitated at a weight of 160-200 g "lean" animals, which were used in all studies unless otherwise specified) or $400-440 \mathrm{~g}$ ("obese"). The epididymal fat pads were immediately excised and minced. Fat cells were isolated in medium 199 with $1 \mathrm{mg} / \mathrm{ml}$ collagenase and $40 \mathrm{mg} / \mathrm{ml}$ BSA. The cells were then filtered through a nylon mesh and washed four times with fresh medium. The preincubations were performed with the indicated agents, lipocrit (packed cell volume) $5-10 \%$, at $37^{\circ} \mathrm{C}$ for $20 \mathrm{~min}$ in the presence of $1 \mathrm{U} / \mathrm{ml} \mathrm{ADA}$. To stop receptor cycling the cells were then energy-depleted with $2 \mathrm{mmol} / \mathrm{KCN}$ for $5 \mathrm{~min}$ prior to the binding assays (unless otherwise specified).

\section{${ }^{14} \mathrm{C}-3-O$-methylglucose transport}

This assay was performed as previously described [23]. Following preincubation with the indicated agents, aliquots of the cell suspension were pulsed with ${ }^{14} \mathrm{C}-3-\mathrm{O}$-methylglucose $(50 \mu \mathrm{mol} / 1,1.0 \mu \mathrm{Ci})$ without prior energy depletion. Glucose uptake was stopped after $5-10 \mathrm{~s}$ with ice-cold phloretin $(0.3 \mathrm{mmol} / 1)$. Cell-associated radioactivity was measured and remaining extracellular 3-O-methylglucose subtracted.

\section{${ }^{125}$ I-insulin binding to intact cells}

To remove insulin, vanadate and other agents from the preincubation period that might directly interfere with binding, the cells were washed four times at $24^{\circ} \mathrm{C}$ in medium 199 with $10 \mathrm{mg} / \mathrm{ml} \mathrm{BSA}$ and $2 \mathrm{mmol} / \mathrm{KCN}$. Control experiments have shown that this procedure is sufficient to dissociate more than $90 \%$ of the bound insulin. Aliquots of cells and medium were transferred to $16^{\circ} \mathrm{C}$ and $0.2 \mathrm{ng} / \mathrm{ml}$ ${ }^{125} \mathrm{I}$-insulin and $0-4.2 \mu \mathrm{g} / \mathrm{ml}$ unlabelled insulin added. After $2 \mathrm{~h}$, when steady-state was reached, specific ${ }^{125}$ I-insulin binding was measured as cell-associated radioactivity remaining after subtracting non-specific binding (in the presence of $4.2 \mu \mathrm{g} / \mathrm{ml}$ unlabelled insulin).

\section{Partial purification of insulin receptors and subsequent ${ }^{125}$ I-insulin binding}

Aliquots of the cell suspension were treated with $0.5 \%$ Triton X-100 in Hepes buffer (50 mmol/l, pH 7.4), containing $10 \mathrm{mmol} / 1 \mathrm{MgSO}_{4}$ and the protease inhibitors leupeptin, aprotinin, pepstatin and phenylmethylsulphonyl fluoride. Following vortex-mixing and freezing at $-80^{\circ} \mathrm{C}$ for $1 \mathrm{~h}$, the cell suspension was thawed and homogenized. After centrifugation at $17,000 \times \mathrm{g}$ for $15 \mathrm{~min}$ at $-4^{\circ} \mathrm{C}$, the triglyceride layer was carefully removed and the infranatant centrifuged at $100,000 \times \mathrm{g}$ for $60 \mathrm{~min}$. The supernatant was applied to a wheat germ agglutinin-agarose column and allowed to recirculate three times. After careful washing, the purified insulin receptors were eluted with $0.3 \mathrm{~mol} / \mathrm{l} \mathrm{N}$-acetylglucosamine in Hepes buffer. Insulin binding was determined by adding $0.2 \mathrm{ng}{ }^{125} \mathrm{I}$-insulin to $100 \mu \mathrm{l}$ of the eluate. After $18 \mathrm{~h}$ at $4^{\circ} \mathrm{C}$ the receptors were precipitated with polyethylene glycol together with IgG and specific binding was measured.

\section{Insulin receptor tyrosine kinase activity}

Triplicate samples $(40 \mu 1)$ of the eluate containing the purified insulin receptors were incubated for $15 \mathrm{~min}$ at $20^{\circ} \mathrm{C}$ with $2 \mathrm{mmol} / 1$ $\mathrm{MnCl}_{2}$ in the absence (when not otherwise indicated) or presence of $4.2 \mu \mathrm{g} / \mathrm{ml}$ insulin. $15 \mu \mathrm{mol} / \mathrm{l}$ ATP was added for $15 \mathrm{~min}$ when $\mathrm{Glu}^{80} \mathrm{Tyr}^{20}(2.5 \mathrm{mg} / \mathrm{ml}),{ }^{32} \mathrm{P}$-ATP $\left(\sim 10^{6} \mathrm{cpm}\right)$ and unlabelled ATP (final concentration $15 \mu \mathrm{mol} / \mathrm{l}$ ) were added to a total volume of $100 \mu \mathrm{l}$ and the incubations continued for another $15 \mathrm{~min} .75 \mu \mathrm{l}$ aliquots were spotted on $3 \mathrm{MM}$ papers (Whatman International, Maidstone, UK), washed with $10 \%$ trichloroacetic acid containing $10 \mathrm{mmol} / \mathrm{N} \mathrm{Na}_{4} \mathrm{P}_{2} \mathrm{O}_{7}$ and then once with $95 \%$ ethanol followed by $95 \%$ acetone. Radioactivity was determined by scintillation counting and the background, obtained from samples lacking $\mathrm{Glu}^{80} \mathrm{Tyr}^{20}$, subtracted.

\section{Statistical analysis}

Statistical significance of differences was tested with Student's twotailed $t$-test for paired data. Results are expressed as means $\pm \mathrm{SEM}$ unless otherwise indicated.

\section{Results}

\section{${ }^{125}$ I-insulin binding to normal cells}

Preincubation with vanadate or insulin at maximally effective concentrations, followed by energy depletion and extensive washing, increased binding 4-5 fold compared to untreated cells (Fig. 1, insert). The effect was dose-dependent with an $\mathrm{EC}_{50}$ (concentration producing $50 \%$ of maximal effect) for vanadate $\sim 0.6 \mathrm{mmol} / \mathrm{l}$ (Fig. 1). No additional response was exerted by concentrations higher than $4 \mathrm{mmol} / 1$ (not shown). Scatchard analysis confirmed that the enhanced insulin binding was due to an increase in 


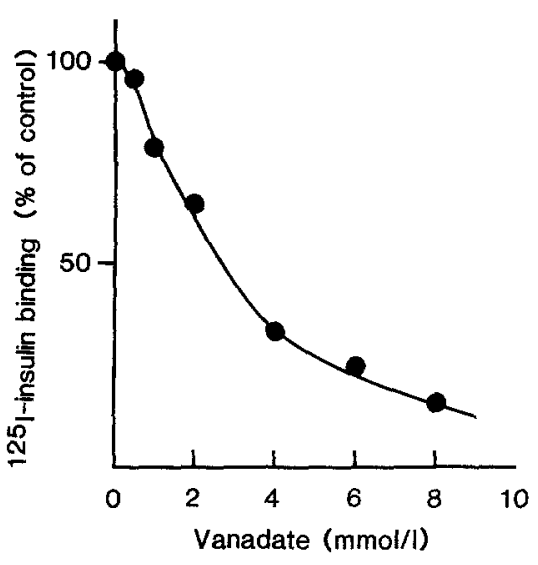

Fig. 2. ${ }^{125} \mathrm{I}$-insulin binding in the presence of vanadate. Adipocytes were treated with $2 \mathrm{mmol} / 1 \mathrm{KCN}$ at $37^{\circ} \mathrm{C}$ for $5 \mathrm{~min}$ without any preincubation period. The cells were transferred to $16^{\circ} \mathrm{C}$ and ${ }^{125} \mathrm{I}$-insulin $(0.2 \mathrm{ng} / \mathrm{ml})$ was added togehter with vanadate at the indicated concentrations. After $2 \mathrm{~h}$ binding was determined as described in "Materials and methods". Data are from one representative experiment repeated three times

the number of cell surface binding sites without any change in binding affinity (not shown).

To investigate if vanadate can directly interact with binding of insulin to its receptor, different concentrations of vanadate were added together with ${ }^{125}$ I-insulin following $\mathrm{KCN}$ treatment. As seen in Figure 2, vanadate inhibited ${ }^{125} \mathrm{I}$-insulin binding and this apparent competition was concentration-dependent, requiring higher vanadate levels ( $\geq 1 \mathrm{mmol} / \mathrm{l})$ than the stimulatory effect.

Experiments were also performed where the two opposite effects (Figs. 1 and 2, respectively) of vanadate, i. e., increase in binding capacity and apparent competition with insulin, were allowed to occur concomitantly. When cells were preincubated with $5 \mathrm{mmol} / \mathrm{l}$ vanadate for $20 \mathrm{~min}$ and
${ }^{125} \mathrm{I}$-insulin then added directly at $37^{\circ} \mathrm{C}$ without prior washing or energy depletion, the net effect was an approximate two-fold increase in insulin binding compared to untreated cells (not shown).

\section{3-O-methylglucose transport in normal cells}

Preincubation of adipocytes with vanadate increased the rate of 3-O-methylglucose transport in a concentrationdependent manner (Fig.3A). Five $\mathrm{mmol} / \mathrm{l}$ vanadate (maximally effective concentration, not shown) and $1000 \mu \mathrm{U} / \mathrm{ml}$ insulin were equally effective and increased the transport rate about 7-8-fold (Fig. $3 \mathrm{~A}$, insert). No additive effect above this was seen by the addition of vanadate together with insulin (not shown).

The effect of vanadate on insulin sensitivity was examined by assessing the dose-response relationship for insulin-stimulated glucose transport (Fig. 3B). Submaximal concentrations of vanadate $(0.5$ and $2 \mathrm{mmol} / \mathrm{l}$, respectively) enhanced insulin sensitivity and this was not explained merely by the insulin-mimetic effect of vanadate since that effect per se would produce a much smaller change (Fig. 3B). The presence of $0.5 \mathrm{mmol} / \mathrm{l}$ vanadate (Fig. 3B) reduced $\mathrm{EC}_{50}$ for insulin (in control cells $23 \pm 7 \mu \mathrm{U} / \mathrm{ml}$ ) by $45 \pm 3 \%(n=4, p<0.001)$, whereas the corresponding effect of $2 \mathrm{mmol} / \mathrm{l}$ vanadate was $60 \pm 2 \%(n=4, p<0.001)$.

\section{cAMP-treated cells}

Figure $4 \mathrm{~A}$ shows ${ }^{125}$ I-insulin binding to cells exposed to the non-metabolizable [24] cAMP-analogue $\mathrm{N}^{6}$ mbcAMP (4 mmol/l). ${ }^{125}$ I-insulin binding was not changed by $\mathrm{N}^{6}$-mbcAMP alone. However, the effect of insulin pretreatment to increase binding (Figure 1, insert) was abolished in the presence of $\mathrm{N}^{6}$-mbcAMP, whereas vanadate

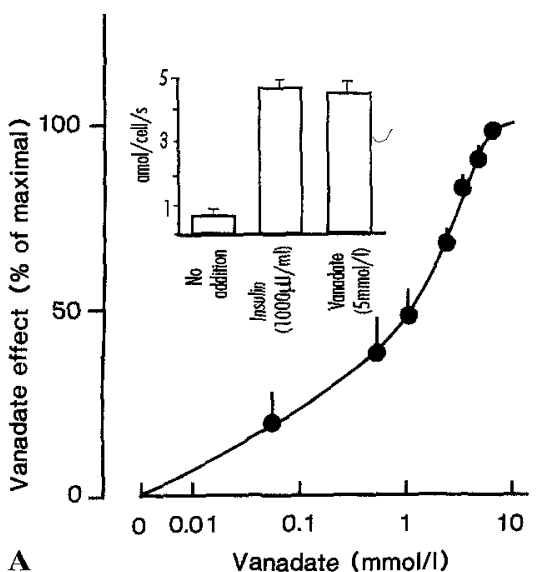

Fig. 3 A, B. ${ }^{14} \mathrm{C}-3$-O-methylglucose transport in normal rat adipocytes. Cells were preincubated at $37^{\circ} \mathrm{C}$ for $20 \mathrm{~min}$ with vanadate or insulin at the indicated concentrations and ${ }^{14} \mathrm{C}-3-\mathrm{O}$-methylglucose transport was assayed (without preceding $\mathrm{KCN}$-treatment). A Dose-response relationship for the effect of vanadate expressed as percent of maximal effect. Insert: maximal effects of insulin and vanadate, respectively. Data are means $\pm S E M$ of five separate experiments. B Dose-response relationship for the effect of insulin in

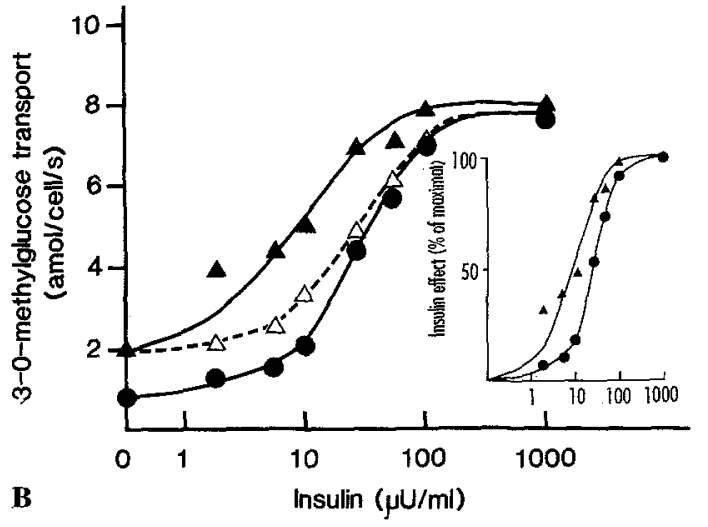

the absence $(\bullet$ ) or presence $(\boldsymbol{\Delta})$ of $0.5 \mathrm{mmol} / \mathrm{l}$ vanadate. $\mathrm{A}$ calculated curve $(\Delta)$ is also shown, representing the sum of insulin and vanadate effects assuming that vanadate $(0.5 \mathrm{mmol} / \mathrm{l})$ exerts only its intrinsic stimulatory action on glucose uptake (corresponding to that of $8 \mu \mathrm{U} / \mathrm{ml}$ of insulin). Insert: Data expressed as percent of the maximal increase. Data are from one representative experiment repeated four times 


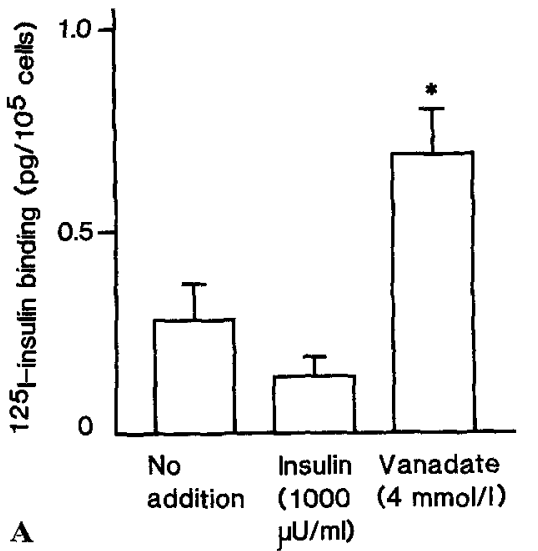

Fig. 4A,B. ${ }^{125} \mathrm{I}$-insulin binding (A) and ${ }^{14} \mathrm{C}$-3-O-methylglucose transport (B) in $\mathrm{N}^{6}$-mbcAMP-treated cells. A Cells were incubated at $37^{\circ} \mathrm{C}$ for $20 \mathrm{~min}$ with $\mathrm{N}^{6}$-mbcAMP $(4 \mathrm{mmol} / \mathrm{l})$ in the presence or absence of insulin and vanadate. Energy depletion and ${ }^{125} \mathrm{I}$-insulinbinding were performed as described in "Materials and methods". Data are means \pm SEM of four separate experiments. ${ }^{*} p<0.02$ compared to addition of $\mathrm{N}^{6}$-mbcAMP alone. B Cells were preincu-

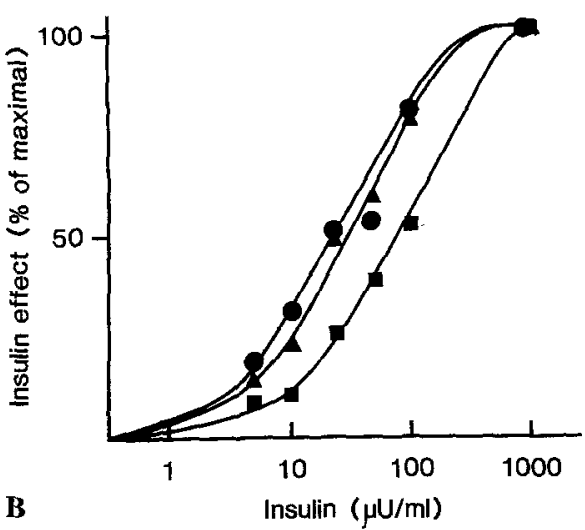

bated at $37^{\circ} \mathrm{C}$ for 20 min with different concentrations of insulin in the presence of $4 \mathrm{mmol} / 1 \mathrm{~N}^{6}$-mbcAMP ( $), 0.5 \mathrm{mmol} / 1$ vanadate and $\mathrm{N}^{6} \mathrm{mbcAMP}(\boldsymbol{\Delta})$ or in the absence of these agents $(-) \cdot{ }^{14} \mathrm{C}-3-\mathrm{O}$ methylglucose transport was then assayed. Data are from one representative experiment repeated four times and the insulin effect is expressed as percent of maximal

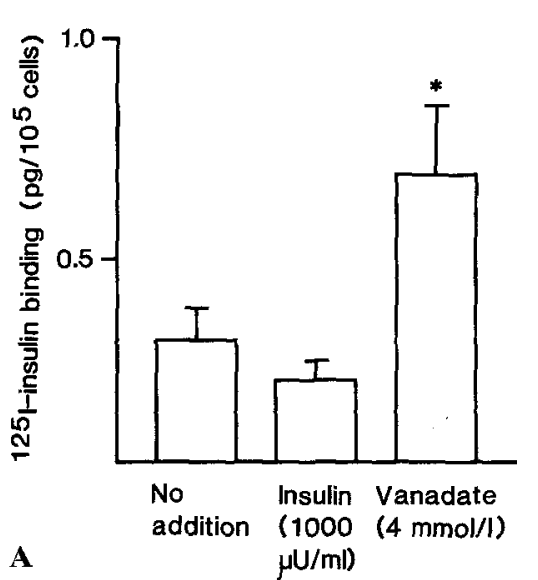

Fig.5 A, B. ${ }^{125}$ I-insulin binding (A) and ${ }^{14} \mathrm{C}-3-\mathrm{O}$-methylglucose transport $(\mathbf{B})$ in adipocytes from obese aging rats. A Adipocytes from rats weighing $400-440 \mathrm{~g}$ were preincubated as described in Figure 1 . KCN was added and ${ }^{125} \mathrm{I}$-insulin binding determined. Data are means \pm SEM of five separate experiments. ${ }^{*} p<0.05$ compared to no addition. $\mathbf{B}{ }^{14} \mathrm{C}-3-\mathrm{O}$-methylglucose uptake was assessed in adipocytes preincubated at $37^{\circ} \mathrm{C}$ for 20 min with different concentrations

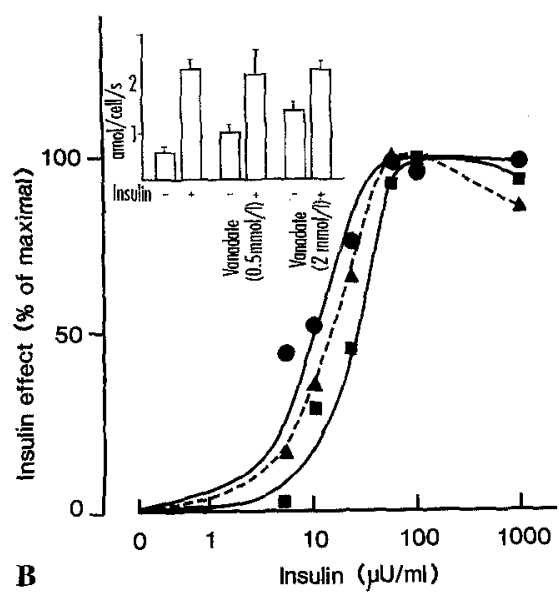

of insulin. The cells were obtained either from young lean rats $(160$ $200 \mathrm{~g}, \mathbf{0})$ or from obese rats $(400-440 \mathrm{~g})$, with the latter cells being preincubated in the presence $(\boldsymbol{\Delta})$ or absence $(\boldsymbol{\square})$ of vanadate $(0.5 \mathrm{mmol} / \mathrm{l})$. Data are from one representative experiment of three. Insert: Absolute response to insulin $(1000 \mu \mathrm{U} / \mathrm{ml})$ in the absence or presence of vanadate in adipocytes from obese rats. Data are means $\pm S E M$ of three to six separate experiments was still able to increase binding. The dose-response relationship for the vanadate-induced increase in insulin binding was similar to that in control cells (not shown).

The cellular sensitivity to the effect of insulin to stimulate 3-O-methylglucose transport was markedly impaired by $\mathrm{N}^{6}$-mbcAMP (EC $\mathrm{EC}_{50} 48 \pm 11$ vs $20 \pm 1 \mu \mathrm{U} / \mathrm{ml}$ in control cells, $n=4, p<0.05$, Fig. 4B). However, when exposed to $0.5 \mathrm{mmol} / \mathrm{l}$ vanadate, $\mathrm{N}^{6}$-mbcAMP-treated cells displayed a normal sensitivity to insulin ( $\mathrm{EC}_{50} 22 \pm 4 \mu \mathrm{U} / \mathrm{ml}, n=4$, Fig.4B). Two $\mathrm{mmol} / \mathrm{l}$ vanadate further increased the sensitivity to insulin to a "supranormal" level $\left(\mathrm{EC}_{50}\right.$ $11 \pm 4 \mu \mathrm{U} / \mathrm{ml}, n=4)$. The maximal response to insulin was not significantly changed by $\mathrm{N}^{6}$-mbcAMP and no additional response was seen in the presence of vanadate (not shown).

\section{Amiloride-treated cells}

The diuretic agent amiloride impairs insulin sensitivity in rat adipocytes, probably in part through a decreased effect of insulin to enhance receptor binding [22]. There was no difference in basal ${ }^{125} \mathrm{~T}$-insulin binding between control cells and cells treated with $1 \mathrm{mmol} / 1$ amiloride (not shown). However, the effect of insulin to increase binding was severely blunted, whereas vanadate elicited an essentially normal response (not shown). As was seen with $\mathrm{N}^{6}$-mbcAMP-treated cells, vanadate $(0.5 \mathrm{mmol} / \mathrm{l})$ prevented the effect of amiloride to decrease insulin sensitivity assessed from the dose-response curve for insulin-stimulated 3-O-methylglucose transport (not shown). 


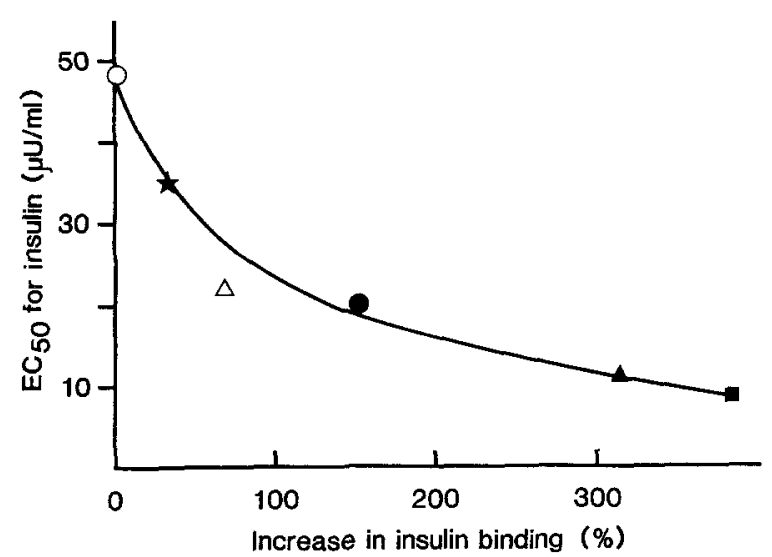

Fig.6. Relationship between the enhancing effect on insulin binding and $\mathrm{EC}_{50}$ for insulin action on glucose transport. Calculated values for the increase in ${ }^{125} \mathrm{I}$-insulin binding (at an insulin concentration of $20 \mu \mathrm{U} / \mathrm{ml}$, i. e., at $\sim \mathrm{EC}_{50}$ ) produced by either insulin itself and/or vanadate vs measured $\mathrm{EC}_{50}$ for insulin-stimulated ${ }^{14} \mathrm{C}$-3-O-methylglucose transport. The enhancement in insulin binding at $\mathrm{EC}_{50}$ was calculated from complete dose-response curves $(n=4)$. Data are obtained from the different experiments presented in "Results": control cells $(\bullet)$, cells treated with $0.5 \mathrm{mmol} / 1$ vanadate $(\boldsymbol{A})$, $2 \mathrm{mmol} / \mathrm{l}$ vanadate $(\mathbf{m}), 4 \mathrm{mmol} / \mathrm{l} \mathrm{N}^{6}-\mathrm{mbcAMP}(\mathrm{O}), 4 \mathrm{mmol} / \mathrm{l} \mathrm{N}^{6}-$ $\mathrm{mbcAMP}$ plus $0.5 \mathrm{mmol} / \mathrm{l}$ vanadate $(\triangle)$ or $1 \mathrm{mmol} / 1$ amiloride $\left({ }^{*}\right)$

\section{Cells from aging, obese rats}

Pretreatment of cells from old, obese rats with insulin did not increase insulin binding, whereas vanadate again produced a clear increase (Fig. 5 A). However, the relative effect of vanadate was lower than in control cells (approximately two-fold above basal). As in the other insulin-resistant states, vanadate $(0.5 \mathrm{mmol} / \mathrm{l})$ was capable of improving the impaired sensitivity to the effect of insulin on glucose transport and reduced $\mathrm{EC}_{50}$ for insulin by $60 \pm 7 \%$ $(n=3, p<0.02$, Fig. $5 \mathrm{~B})$. The maximal response to insulin was reduced in obese compared to control cells, (Fig. 5B vs $3 \mathrm{~A}$, inserted graphs), and it was not enhanced by vanadate.

\section{Insulin receptor tyrosine kinase activity}

Preincubation of the adipocytes with insulin induced a dose-dependent increase in the tyrosine kinase activity of partially purified insulin receptors (not shown). At the insulin concentrations used $(0,10,25,1000 \mu \mathrm{U} / \mathrm{ml})$ vanadate $(2 \mathrm{mmol} / \mathrm{l})$ added to cells exerted an additive effect and increased the tyrosine kinase activity approximately two-fold compared to cells incubated without vanadate $(n=3-5, p<0.05)$.

\section{Discussion}

This study clearly shows that the effect of vanadate to rapidly and markedly increase cell surface insulin binding capacity in normal rat adipocytes [17] is also demonstrable in insulin-resistant cells. This differs from the effect of insulin, which was seen only in normal, insulin- sensitive cells. However, there are apparently two counteracting components of vanadate action on insulin binding. Firstly, preincubation of normal adipocytes with a maximally effective vanadate concentration up-regulates the number of available binding sites approximately five-fold. Secondly, vanadate exerts a direct inhibitory effect on insulin binding, which may suggest a competition between insulin and vanadate at the insulin-binding region of the receptor $\alpha$-subunit or, alternatively, a direct effect of vanadate on the insulin molecule itself. The two opposing effects of vanadate may explain some previous results with this agent showing an increase of much smaller magnitude ( $40 \%$ increase) [16] than presently demonstrated or even a decrease [14] in insulin binding. However, the net result of the two opposite effects of vanadate under physiological conditions is clearly an increase in insulin binding, demonstrated in the experiments where the cells were not energy-depleted and vanadate was present during the binding assay.

Recently, Fantus et al. [16] reported that the effect of vanadate in augmenting insulin binding in rat adipocytes reaches maximum at a very low vanadate concentration $(0.2 \mathrm{mmol} / \mathrm{l})$. The reasons that this was seen at higher concentrations of vanadate $(\sim 4 \mathrm{mmol} / \mathrm{l})$ in the present work may be: (1) the removal of vanadate prior to the binding assays thus dissociating the inhibitory component of vanadate action on insulin binding, (2) the degradation of adenosine by ADA, which per se impairs the cellular sensitivity to both insulin [25] and vanadate (not shown) and (3) a shorter time of vanadate exposure (20 vs $120 \mathrm{~min}$ ).

The mechanisms for this novel effect of insulin and vanadate in enhancing the number of cell surface binding sites are still unclear as discussed extensively elsewhere [17]. However, recent data with affinity labelling of ${ }^{125} \mathrm{I}$-insulin to intact fat cells show that the increased binding is recovered in isolated plasma membranes and that it occurs at the $\alpha$-subunit of the insulin receptor as shown with SDS-PAGE combined with autoradiography (to be published).

It may be expected that the increase in insulin binding exerted by vanadate leads to an enhanced cellular sensitivity to insulin. This was studied by assessing the concentration-response relationship for the ability of insulin to stimulate 3-O-methylglucose transport. The presence of submaximal vanadate concentrations, with less than halfmaximal intrinsic stimulatory action, clearly shifted the concentration-response curve for insulin to the left, indicating a greater sensitivity to insulin. This effect was not explained by the mere insulin-mimetic effect of vanadate, since the increase in insulin sensitivity would then have been much smaller. Instead, the enhanced insulin sensitivity ( $\sim$ two-fold) corresponds to the increased insulin-binding capacity ( $\sim$ two-fold) following exposure to $0.5 \mathrm{mmol} / \mathrm{l}$ vanadate. Furthermore, the enhanced insulin sensitivity demonstrated is underestimated rather than overestimated, since the additional response induced by vanadate was most pronounced at low insulin concentrations.

To investigate whether vanadate-treatment in vitro is also efficient in insulin-resistant cells, we studied three different conditions of impaired insulin sensitivity, namely cells treated with $\mathrm{N}^{6}$-mbcAMP [24-27], amiloride [22] and 
cells from aging, obese rats [28]. The effect of insulin in increasing the number of cell surface binding sites is abolished or severely blunted in all these conditions indicating an importance of this effect in the regulation of insulin sensitivity. In contrast to insulin, vanadate produced a marked increase in insulin binding in all the insulin-resistant states studied. Accordingly, submaximal vanadate concentrations improved the sensitivity to the effect of insulin in stimulating glucose transport in the insulin-resistant cells. Figure 6 shows an attempt to assess the relationship between $\mathrm{EC}_{50}$ for insulin-stimulated 3-O-methylglucose transport and the calculated increase in binding at the $\mathrm{EC}_{50}$ level of insulin. When data from cells of varying degrees of insulin sensitivity in the presence or absence of different vanadate concentrations are compared, there is an apparently negative, non-linear correlation between the increase in insulin binding and $\mathrm{EC}_{50}$ for insulin, supporting the importance of alterations in binding for insulin sensitivity. This also gives a fitting quantitative relationship with a two-fold increase in binding leading to an approximately $50 \%$ reduction in $\mathrm{EC}_{50}$. In this context it is interesting that in vivo, long-term treatment of diabetic rats or mice with vanadate can normalize the blood glucose levels as well as insulin-mediated glucose disposal and glycogen synthase activity [29-32].

Additional support for the importance of the increase in insulin binding for the effect of vanadate to enhance insulin sensitivity was provided by its failure to augment the maximal response to insulin in insulin-resistant cells. Had there been such an effect of vanadate, this would argue instead for the importance of post-receptor mechanisms [33]. Our data are thus in congruence with those of Fantus et al. [16] but conflict with the results of Green [13] who proposed an important post-receptor action of vanadate. This was based on a preserved effect on glucose uptake even when the cell surface receptors had been down-regulated or degraded by trypsin. One possibility for reconciling these observations with ours may be that the insulin-like response exerted by vanadate occurs mainly through post-receptor mechanisms, whereas the ability of vanadate to increase the cellular sensitivity to insulin is associated with an interaction at the insulin receptor level.

The insulin receptor tyrosine kinase has been proposed to play an important role both for the insulin signalling process $[7,9]$ and for vanadate action $[8,10]$. However, there are also results suggesting that insulin [34] as well as vanadate $[11,12]$ may act independently of this enzyme. The present data show an additive effect of vanadate on insulin-stimulated tyrosine kinase activity but the impact of this for the effect of vanadate on insulin sensitivity is unclear. It is conceivable that both the increase in insulin binding and the augmented tyrosine kinase activity contribute to an amplification of the insulin signal and, thus, increase the insulin sensitivity. It is also possible that following vanadate or insulin binding, the stimulation of the tyrosine kinase occurs first and induces the increase in binding capacity either as a "positive feed-back" mechanism changing the conformation of the initially occupied receptor or through a lateral transphosphorylation and activation of neighbouring receptors [35]. The opposite order, i. e., a conformational change leading to tyrosine kinase activation, is less likely, since we have demonstrated in insulin-resistant states (obesity, $\mathrm{N}^{6}$-mbcAMP-treatment) a normal or only slightly impaired tyrosine kinase activity [17] despite an abolished ability of insulin to increase binding.

In conclusion, the present data show that short-term exposure to insulin or vanadate increases cell surface insulin binding capacity in normal rat adipocytes. In contrast to insulin, the effect of vanadate was also demonstrable in insulin-resistant cells. The increase in insulin binding following vanadate is associated with an enhanced cellular sensitivity to insulin both in normal and insulin-resistant cells.

Acknowledgements. This study was supported by grants from the Swedish Medical Research Council (grant B-3506), the King Gustaf and Queen Victoria Fund, the Gothenburg Medical Society and the Gothenburg Diabetes Association. We are grateful to Ms B. Karlsson-Svalstedt, Ms C. Goldmarck and Ms B. Carlander for expert technical assistance and to Ms A-L.Dahlgren for excellent secretarial help.

\section{References}

1. Tolman EL, Barris E, Burns M, Pansini A, Partridge R (1979) Effects of vanadium on glucose metabolism in vivo. Life Sci 25 : 1159-1164

2. Shechter Y, Karlish SJD (1980) Insulin-like stimulation of glucose oxidation in rat adipocytes by vanadyl ions (IV) ions. Nature (Lond) 284: 556-558

3. Dubyak GR, Kleinzeller A (1980) The insulin-mimetic effects of vanadate in isolated rat adipocytes. J Biol Chem 255: 5306-5312

4. Tamura S, Brown TA, Dubler RE, Larner J (1983) Insulin-like effect of vanadate on adipocyte glycogen synthase and on phosphorylation of 95,000 dalton subunit of insulin receptor. Biochem Biophys Res Commun 113: 81-86

5. Jackson TK, Salhanick AI, Sparks JD, Sparks CE, Bolognino M, Amatruda JM (1988) Insulin-mimetic effects of vanadate in primary cultures of rat hepatocytes. Diabetes 37: 1234-1240

6. Duckworth WC, Solomon SS, Liepnieks J, Hamel FG, Hand S, Peavy DE (1988) Insulin-like effects of vanadate in isolated rat adipocytes. Endocrinology 122: 2285-2289

7. Rosen OM, Herrera R, Olowe Y, Petruzzelli LM, Cobb MH (1983) Phosphorylation activates the insulin receptor tyrosine protein kinase. Proc Natl Acad Sci 80: 3237-3240

8. Tamura S, Brown TA, Whipple JH et al. (1984) A novel mechanism for the insulin-like effect of vanadate on glycogen synthase in rat adipocytes. $\mathrm{J}$ Biol Chem 259: 6650-6658

9. Avruch J, Alexander MC, Palmer JL et al. (1982) Role of insulinstimulated protein phosphorylation in insulin action. Fed Proc 41: 2629-2633

10. Bernier M, Laird DM, Lane MD (1988) Effect of vanadate on the cellular accumulation of $\mathrm{pp} 15$, an apparent product of insulin receptor tyrosine kinase action. J Biol Chem 263: 13626-13634

11. Mooney RA, Bordwell KL, Luhowskyj S, Casnellie JE (1989) The insulin-like effect of vanadate on lipolysis in rat adipocytes is not accompanied by an insulin-like effect on tyrosine phosphorylation. Endocrinology 124: 422-429

12. Strout HV, Vicario P, Saperstein R, Slater EE (1989) The insulinmimetic effect of vanadate is not correlated with insulin receptor tyrosine kinase activity nor phosphorylation in mouse diaphragm in vivo. Endocrinology 124: 1918-1924

13. Green A (1986) The insulin-like effect of sodium vanadate on adipocyte glucose transport is mediated at a post-insulin-receptor level. Biochem J 238: 663-669 
14. Levin SR, Aftergood DE, Fancus E, Whitson RH (1988) Inhibition of insulin receptors by vanadate and ouabain. Life Sci 42: 1889-1896

15. Marshall S, Monzon R (1987) Down-regulation of cell surface insulin receptors in primary cultured rat adipocytes by sodium vanadate. Endocrinology 121:1116-1122

16. Fantus IG, Ahmad F, Deragon G (1990) Vanadate augments insulin binding and prolongs insulin action in rat adipocytes. Endocrinology 127:2716-2725

17. Eriksson JW, Lönnroth P, Smith U (1992) Insulin can rapidly increase cell surface insulin binding capacity in rat adipocytes - a novel mechanism related to insulin sensitivity. Diabetes (in press)

18. Kono T, Robinson FW, Sarver JA, Vega FV, Pointer RH (1977) Actions of insulin in fat cells. J Biol Chem 252:2226-2233

19. Suzuki K, Kono T (1979) Internalization and degradation of fat cell-bound insulin. J Biol Chem 254: 9786-9794

20. Sonne $O(1986)$ The reversible receptor binding of insulin in isolated rat adipocytes measured at $37^{\circ} \mathrm{C}$. The binding is not rate limiting for cellular uptake. Biochim Biophys Acta 886: 302-309

21. Wardzala LJ, Simpson IA, Rechler MM, Cushman SW (1984) Potential mechanism of the stimulatory action of insulin on insulin-like growth factor II binding to the isolated rat adipose cell. J Biol Chem 259: 8378-8383

22. Eriksson J, Lönnroth P, Wesslau C, Smith U (1991) Amiloride inhibits insulin sensitivity and responsiveness in rat adipocytes through different mechanisms. Biochem Biophys Res Commun 176: 1277-1284

23. Whitesell RR, Gliemann J (1979) Kinetic parameters of transport of 3-O-methylglucose and glucose in adipocytes. $J$ Biol Chem 254: 5276-5283

24. Beebe SJ, Holloway R, Rammels SR, Corbin JD (1984) Two classes of cAMP analogs which are selective for the two different cAMP-binding sites of type II protein kinase demonstrate synergism when added together to intact adipocytes. J Biol Chem 259: 3539-3547

25. Lönnroth P, Davies JI, Lönnroth I, Smith U (1987) The interaction between the adenylate cyclase system and insulin-stimulated glucose transport. Biochem J 243: 789-795

26. Taylor WM, Mak ML, Halperin ML (1976) Effect of 3':5'-cyclic AMP on glucose transport in rat adipocytes. Proc Natl Acad Sci 73: $4359-4363$
27. Kirsch D, Kemmler W, Häring HU (1983) Cyclic AMP modulates insulin binding and induces post-receptor insulin resistance of glucose transport in isolated rat adipocytes. Biochem Biophys Res Commun 115: 398-405

28. Foley JE, Laursen AL, Sonne O, Gliemann J (1980) Insulin binding and hexose transport in rat adipocytes. Diabetologia 19: 234-241

29. Heyliger CE, Tahiliant AG, McNeill JH (1985) Effect of vanadate on elevated blood glucose and depressed cardiac performance of diabetic rats. Science 227: 1474-1476

30. Blondel O, Bailbe D, Portha B (1989) In vivo insulin resistance in streptozotocin-diabetic rats - evidence for reversal following oral vanadate treatment. Diabetologia 32: 185-190

31. Rossetti L, Laughlin MR (1989) Correction of chronic hyperglycemia with vanadate, but not with phlorizin, normalizes in vivo glycogen repletion and in vitro glycogen synthase activity in diabetic skeletal muscle. J Clin Invest 84: 892-899

32. Meyerovitch J, Rothenberg P, Shechter Y, Bonner-Weir S, Kahn CR (1991) Vanadate normalizes hyperglycemia in two mouse models of non-insulin-dependent diabetes mellitus. J Clin Invest 87: 1286-1294

33. Kahn CR (1978) Insulin resistance, insulin insensitivity and insulin unresponsiveness: a necessary distinction. Metabolism 27 [Suppl 2]: 1893-1902

34. Goldfine ID (1987) The insulin receptor: Molecular biology and transmembrane signaling. Endocr Rev 8: 235-255

35. Lammers R, van Obberghen E, Ballotti R, Schlessinger J, Ullrich A (1990) Transphosphorylation as a possible mechanism for insulin and epidermal growth factor receptor activation. J Biol Chem 265: 16886-16890

Received: 8 November 1991

and in revised form: 20 January 1991

Dr. J.Eriksson

Department of Medicine II

Sahlgren's Hospital

S-41345 Gothenburg

Sweden 